\title{
Developing Co-constructivism Scale at Science Courses for Secondary School Students*
}

\section{Ortaokul Öğrencileri için Fen Bilimleri Dersinde Birlikte Yapılandırmacılık Ölçeğinin Geliştirilmesi}

\author{
İjlal OCAK ${ }^{* *}$ (iD) Nilda HOCAOĞLU*** (iD
}

Received: 08 March 2021

Research Article

Accepted: 03 September 2021

ABSTRACT: According to co-constructivism theory, learning is a social activity. Students are expected to find many opportunities at Science lessons to construct their collective culture and co-construct their culture since science lessons tend to collaborate. This study aims to develop a scale that measures the co-constructivist environment at $7^{\text {th }}$ and $8^{\text {th }}$ Grades science courses. For this reason, the scale developed by the researchers has been applied to $2387^{\text {th }}$ and $8^{\text {th }}$ grade students. Exploratory Factor Analysis has been applied for 47 items. As a result of factor analysis, 20 items have been omitted, and the remaining 27 items have been grouped into five factors. These factors explain $64.371 \%$ of the total variance. Cronbach Alpha value of the scale is .950. The values of item-total and item-remaining correlation are significant $(p<.01)$. Moreover, the item discrimination value obtained from the difference between mean points of bottom and top $27 \%$ of the groups is significant. As a result of confirmatory factor analysis, goodness of fit indexes are seen to be acceptable (RMSEA=.084; $\mathrm{AGFI}=.70$; $\mathrm{SRMR}=.064 ; \mathrm{CFI}=.91 ; \mathrm{NNFI}=.09, \chi^{2} / s d=1.93$ ). It was found that the qualitative results mostly coincided with the results of the quantitative study.

Keywords: Co-constructivism, science education, scale development, exploratory factor analysis, confirmatory factor analysis.

ÖZ: Birlikte yapılandırmacılık teorisine göre öğrenme sosyal bir aktivitedir. Fen derslerinin doğası iş birliği eğilimi gösterdiğinden, öğrencilerin Fen derslerinde kolektif kültürlerini oluşturmak ve kendi kişisel kültürlerini birlikte oluşturmak için birçok firsat bulmaları beklenir. Bu çalışma, 7. ve 8. sınıf Fen derslerinde birlikte yapılandırmacılık ortamını ölçen bir ölçek geliştirmeyi amaçlamaktadır. Bu nedenle araştırmacılar tarafından geliştirilen ölçek, 2387. ve 8. sınıf öğrencisine uygulanmıştır. 47 maddeye Açımlayıcı Faktör Analizi uygulanmıştır. Faktör analizi sonucunda 20 madde çıkarılmış ve kalan 27 madde 5 faktörde gruplandırılmıştır. Bu faktörler toplam varyansın \%64.371'ini açıklamaktadır. Ölçeğin Cronbach Alpha değeri .950'dir. Bu bulgular 1şığında ölçek geçerli ve güvenilirdir. Maddetoplam ve madde-kalan korelasyon değerleri anlamlıdır $(p<0.01)$. Ayrıca grupların $\% 27$ lik alt ve üst puan ortalamaları arasındaki farktan elde edilen madde ayırt etme değeri anlamlıdır. Doğrulayıcı faktör analizi sonucunda uyum iyiliği indekslerinin kabul edilebilir olduğu görülmektedir (RMSEA=.084; AGFI=.70; SRMR=.064; CFI=.91; $\left.\mathrm{NNFI}=.80, \chi^{2} / s d=1.93\right)$. Nitel sonuçların da nicel çalışmanın sonuçlarıyla çoğunlukla örtüştüğü bulunmuştur.

Anahtar kelimeler: Birlikte yapılandırmacılık, fen eğitimi, ölçek geliştirme, açımlayıcı faktör analizi, doğrulayıcı faktör analizi.

\footnotetext{
* A short text of this study was presented in "Hands-on Science, Advancing Science, Improving Education", an international conference in Barcelona, 16-20 July, 2018.

** Prof. Dr., Afyon Kocatepe University, Afyonkarahisar, Turkey, iocak@aku.edu.tr, https://orcid.org/0000-00016976-5747

*** Corresponding Author: Lecturer, Afyon Kocatepe University, Afyonkarahisar, Turkey, nhocaoglu@aku.edu.tr, https://orcid.org/0000-0002-3456-095X
}

Citation Information

Ocak, İ., \& Hocaoğlu, N. (2021). Developing co-constructivism scale at science courses for secondary school students. Kuramsal Eğitimbilim Dergisi [Journal of Theoretical Educational Science], 14(4), 665-696. 
The educational constructivism of personal diversity emphasizes the individual creation of knowledge and the construction of concepts. This stream can be traced back to the Kantian theories of Piaget's cognitive development. The educational constructivism of social variety emphasizes the importance of the group for developing and confirming ideas. This has its roots in Vygotsky's work in linguistics and language acquisition and is seen, for example, in Rosalind Driver's later publications (Matthews, 1998, p. 3). Constructivism's perspectives on the role of the individual, the importance of meaning-making, and the learner's active role are the very factors that make theory attractive to teachers. Teachers are usually very conscious of the role of prior knowledge in student learning. They acknowledge that the students are not empty slates waiting to be filled with knowledge. Instead, students bring a wealth of previous experiences, knowledge, and beliefs to develop new knowledge (Jones \& Brader-Araje, 2002). For Piaget, the construction of knowledge is achieved when new knowledge is actively assimilated and integrated into existing knowledge. Social constructivism avoids the idea that individual cognition is the only driving force behind the construction of knowledge (Hyslop-Margison \& Strobel, 2008). According to radical constructivism, knowledge is in the heads of the people. The thinking individual is left with no choice but to construct what he or she understands from personal experience (Jones \& Brader-Araje, 2002).

Co-constructivism aims to unite two separate concepts: constructivism and sociogeneticism, seen as opposite domains. Contemporary developmental psychology includes two main oppositional ideas, which causes the emergence of the concepts like co-constructivism. First, there is a contrast between these assumptions; one is that the psychological functions are given assets, and the other is that the organisms construct these functions throughout their lives. Constructivism emerges from this ontological assumption as an opposite solution. It is asserted that psychological functions are constructed rather than pre-existing assets (Valsiner, 1996). The focus here is on the axiomatic declaration of the origin of these functions and the nature of their functioning. From the standpoint of their current existence, the two perspectives converge. These viewpoints can be traced from this example: A child's solving of a puzzle can be interpreted as the child's construction of a solution (as a perspective of constructivism) or as the child's finding a solution (as a non-constructivist view since the assumption of the pre-existing solution). Through constructivism, the child tries to develop or make up the solution. In contrast, through the perspective of the non-constructivist view, the child tries to find a solution under the assumption of the solution that already exists (Valsiner, 1996).

Secondly, how psychological functions exist causes individual and social (interindividual) opposition (Valsiner, 1996). Two widespread opinions on society relationship (individual affecting society and society affecting person) have led to the views of social scientists. Both models have prevented conceptualization of psychology for the mutuality of the relationship between individuals and society. Many psychological concepts that can start from phenomena of mutuality as stated intuitively (for example, the idea of attachment or bonding that causes requires reference to a relation) are translated into theoretical and methodological dimensions of psychology into assets that belong to the individual or the environment (Valsiner, 1996). For example, the concept of attachment has resulted in an empirically determinable property 
of the child with the initial focus on a relationship irreversibly lost in the translation process (Valsiner, 1996). Therefore, the co-constructionist view tries to put the individual and the society together because of mutuality and interdependence.

The concept of co-constructivism sees individual uniqueness as proof of the social origins of the human psychological ontogeny (Branco \& Valsiner, 1997). It combines personal locations of psychological functions with their social origins. Coconstructivism does not aim to distinguish the social and the individual within the psyche. Instead, it seeks to find opportunities to conceptualize these two sides together mutually and systematically. The individual's psychological functions are personal in their present case, but they are social in their origins and interdependent with their social surrounding to sustain themselves (Valsiner, 1996). According to Speed (1991), reality is constructed or negotiated through the ideas of individuals or groups in the sense that different forms are emphasized. These thoughts are generated from the social groups in which people join.

The co-constructionist line in theory building may appear to be a recent development, yet this is only an illusion based on the ignorance of the history of psychology. All of the great sociogenetic thinkers in the past advocated for some form of co-constructionist thinking. The co-constructionist flavor of their work is only overlooked when their contributions are forced into artificial restricting categories of cognitive or social emphases. One of the first empirical demonstrations of the coconstructivist process is Frederic Bartlett's work. Sherif's (1936) renowned investigations of how social norms are collaboratively produced in social group settings are an empirical extension of co-constructivist views. A significant role of the inventor of the co-constructivist idea belongs to James Mark Baldwin, whose impact upon the work of both Piaget and Vygotsky was significant. The sociogenetic interests in contemporary psychology and education have mediated much of the interest in Vygotsky's heritage. As a result, the person-centeredness of his approach has been neglected. Internalization is a crucial idea in his sociogenetic theory. Using sign systems, the developing individual actively converts inter-personal experience into an intra-personal form. Semiotic mediation of human psychological functions is a significant component of his philosophy, and it exists in both the inter-personal and intra-personal worlds. As a result, the dual but interdependent presence of the personal and social worlds exists and is emphasized as development progresses. He followed James Mark Baldwin's lead and developed his views in line with William Stern's (Valsiner, 1996).

Co-constructivism is a type of sociogenetic personology (study of personal traits) (Lyra \& Valsiner, 1998, p. 187). Sociogenetic thinkers point out that all or at least higher psychological functions of human beings are socially constructed. This causes the active person, who structures his/her psychological world constantly to relate it to the outside world, to retain his/her central role and the historical priority of the social world. Thus, the development of a human being is described by developing his/her psychological system and the common constructing with the goal-oriented social others who offer social suggestions to him/her (Geert et al., 1994, p. 249-250). The sociogenetic approach of this theory places a special emphasis on the uniqueness of individual people in terms of being culturally bound. In other words, people are microlevel (personal-cultural) parts of a macro-level entity (collective culture). The 
relationship between the two levels can be defined as bidirectional cultural transformation. On the one hand, collective culture occurs in the field of common meanings of the social group. On the other hand, each individual structures his/her own collective culture and actively structures his/her culture together (Lyra \& Valsiner, 1998, p. 187). Therefore, personal and collective culture interacts inseparably.

Learning is a constructive process and social activity, so students should not be seen as solo learners. Instead, they interact with each other and shape their learning through collaboration. Therefore, personal development is not based on isolation while constructing knowledge; rather, its basis comes from co-construction in a cultural environment through a social way (Reusser \& Pauli, 2015). Students are common constructors of their culture and contribute to the innovations of collective culture. The developing human is an active and constructive individual, acting in a highly heterogeneous environment provided by collective culture. The heterogeneity of collective culture is found mainly in the semiotic dimension of social reality. The semiotic knowledge structuring of an active person, including collective cultural suggestions, gives a dynamic form to the developmental process. Collective culture establishes (explicitly or implied) numerous physical and semiotic forms. In the process of co-constructivism, the individual constructs his/her self in detail and reconstructs some aspects of the macro-level environment when the circumstances allow (Lyra \& Valsiner, 1998, p. 187-188). Critical interaction and microgenetic analysis emphasize how human beings' interactions with each other and with objects in their environment their learning and change processes. They automatically co-construct larger social and cultural structures, relations, and processes (Philip \& Gupta, 2020).

Figure 1

\section{Co-constructivist Description of Child Development through Constructed}

\section{Contexts}

COLLECTIVE CULTURE

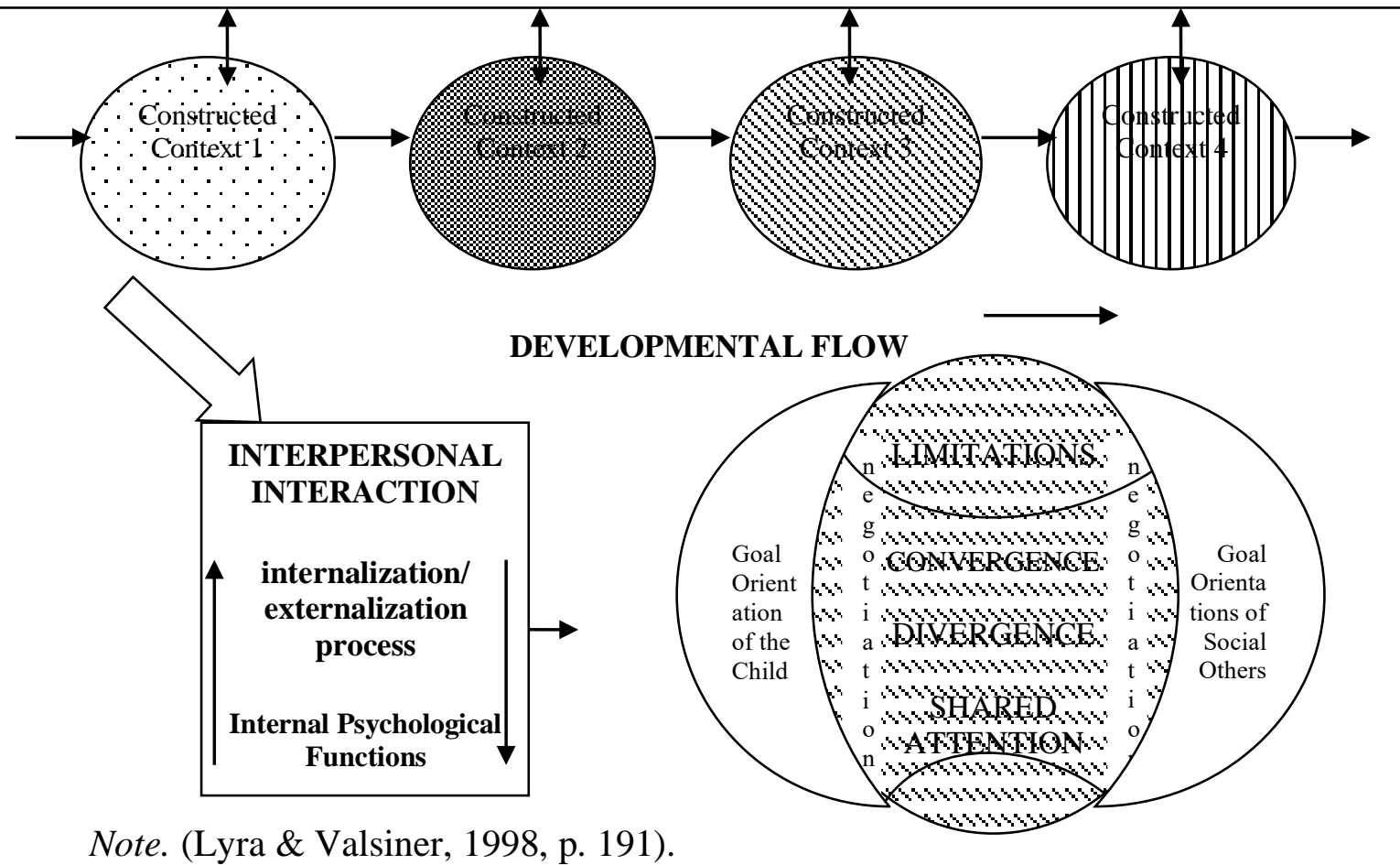

Note. (Lyra \& Valsiner, 1998, p. 191). 
Figure 1 represents the developmental flow of a child while he/she is moving towards successfully constructed contexts. Contexts can overlap, but in some cases, they transform to each other dynamically over time. For example, being at a museum or in a library creates a kind of overlap in these constructed contexts. How students interact with these spaces may have divergence in terms of students' motivation. Boys may demonstrate rude behavior among their friends but being at a museum or in a library requires behaving in a certain manner. Boys have to negotiate to reach convergence because of the limitations, such as the rules of being at a museum. Constructed contexts naturally consist of parts of collective culture. Still, they are open to innovations created by co-constructivist processes that arise from concrete social interactions (Lyra \& Valsiner, 1998, p. 192). This developmental flow can happen both in a formal or informal context since these contexts can overlap. For example, the interaction among children can occur in a playground or a scientific contest. Successfully constructed context may indicate the situation of reconciliation through concrete social interactions. The content of each structure presents certain limitations arising from social participation rules and expectations. Participating individuals continuously reconcile with their goal orientations at the intersection of individuals' interactions and internal psychological orientations when the internalization-externalization processes actively coordinate the behavior of individuals. Thanks to the dialectical movements that manage such processes, the child's perspective co-constructs a synthesis from interests and meanings. Reconciliation processes constantly occur during the sequence of goal orientations. Limitations are determined by how the context is constructed and created by the goal orientation of the individuals who interact with each other (Lyra \& Valsiner, 1998, p. 192). Hence, it can be said that limitations are shaped by both the constructed contexts and the goal orientations.

The child moves with dynamic interaction around him/herself through coconstructivist interactions. As the child grows, such contexts and the nature of social others playing an essential role in the child's emotional-sociocognitive development will also change. The child plays an active role in the process of developing his/her culture. However, it is embedded in the cultural canalization process, put forward by the constructed contexts. The child uses the elements of shared culture as an input to develop his/her culture. It creates a personal type that changes as internal psychological orientations on this input. As shown in Figure 1, the mutual co-construction between personal and collective culture emerges through internalization-externalization (Lyra \& Valsiner, 1998, p. 192). During this process, interpersonal interaction has a significant role since it contributes a lot to cultural forms.

Culture can be seen as an organizational form that directs the next state of human structure. The focus of co-construction leads to restructuring hierarchical organization within structures (Geert et al., 1994, p. 279-280). It is crucial to structure a goal-oriented individual who acts in consciously constructed surroundings and interacts purposefully with other people (Valsiner, 1996). The process of human development is dynamically goal-oriented. Accordingly, any participant can create a goal, try to achieve it, change previously targeted goals, or abandon these goals altogether. Being goaloriented does not mean that goals can be maintained statically. This only emphasizes the future constructivist orientation of psychological processes (Geert et al., 1994, p. 279). In other words, culture has a crucial role in the developmental flow of the human being, 
and human development is a goal-oriented process. In such an environment where the people interact with others purposefully, constructing people who have motivation is a significant aim of co-constructivism. In this perspective, culture and motivation are embedded since there should be a negotiation between the child and the others' goal orientation.

Instead of passively receiving information, children interpret their experiences genius by reorganizing their mental structures in increasingly difficult ways to make sense of their worlds. According to symbolic interactionism and sociocultural theory, learning occurs through social activity and is mainly hidden in society and society's knowledge, perspective, and beliefs. People structure their knowledge through personal experiences and conversations with others and social experience and interaction (Reusser, 2001). Thus, personal development and acculturation are not to be socially alone in structuring knowledge but to structure it together in the cultural and social field. In plenty of settings, many learning is a social activity and a cultural sharing. The child develops his/her knowledge within other individuals who feel belonging to a culture. From this perspective, knowledge does not stand alone in every individual's mind. It is dispersed among individuals who have common interactions and conventions. Co-constructivism can be seen as an adult + child interaction or an interaction between a child and someone more capable. From the cognitive point of view, co-constructivism can be seen as a common understanding of two or more individuals as collaborators or a solution to a problem. At the heart of the concept of coconstructivism lie two co-existing activities. These are solving the problem in a collaborative way and structuring and maintaining a common problem area. Coconstructivism requires individuals to acquire, maintain and update a degree of mutual understanding. The best way to support co-constructivist learning is about designing effective collaborative learning environments. Teachers' role in co-constructivist classrooms is to guide students and help them engage in authentic and task-oriented, constructed social interactions (Reusser, 2001).

The majority of studies focus on the ideas of the students and teacher candidates about the constructivism approach. There are also a few scale development studies measuring the constructivist learning environment (e.g. Ağbuba, 2010; Bay et al., 2010; Bukova-Güzel \& Alkan, 2005; Evrekli et al., 2009; Yeşilyurt, 2012). In this context, the most used scale has been CLES (Constructivist Learning Environment Questionnaire) by Taylor and Fraser (1991). The scale has been updated and developed many times (Taylor et al, 1994). This scale was adapted to Turkish by Küçüközer et al. (2012). Tenenbaum et al. (2001) focused on seven categories in the constructivist learning environment scale they developed. Fer and Cirık (2010) studied this scale's language equivalence, validity, and reliability and adapted it to Turkish. Arkün and Aşkar (2010) developed a 7-point Likert-type scale to assess the constructivist learning environment to obtain the opinions of university students on the face-to-face constructivist learning at the higher education level. So, the developed scales aim to measure constructivist learning in general. However, none of these studies addresses co-constructivism, especially in science courses at secondary school education.

It has been proven by many studies that preparing learning environments in which students will learn concepts in a meaningful way, rather than encouraging memorization, is much more effective in learning science subjects. The co-constructivist 
approach aims to foster active participation, intense interaction, and culture sharing through social motivation. The focus of science teaching is to enable the students to recognize nature and the environment. The students should acquire unique knowledge about nature and structure them in their minds to achieve the aims of science learning. To construct the facts about nature, they must observe, conduct experiments and interact with nature. The co-constructivist learning environment allows all these aims of Science teaching. Social constructivist science teaching aims to develop students' scientific thinking skills and, in this way, share, agree, and discuss with their classmates. The learning environment, content, and objectives of Science teaching are designed accordingly. It is accepted that knowledge is acquired in a social environment in constructivist science teaching. If the students work in groups, they share their knowledge with their friends and form a discussion environment; if necessary, they analyze or review this information by conducting experiments. Students build their knowledge and understandings depending on prior information and the sociocultural setting they find themselves. In these sociocultural settings, they are expected to connect learning with everyday contexts. They are expected to reveal current ideas as well as alternative ones (Eastwell, 2002).

The purpose of the scale is to find out whether there are any applications of coconstructivism in Science courses in terms of the interaction and relationship between student and student. One of the basic skills of the Science curriculum is cultural expression and awareness. In accordance with this skill, the students are supposed to fully understand their own culture, respect cultural differences, and have a positive attitude towards them (MEB, 2018, p. 6). From this point of view, co-constructivism gains importance in Science courses, as well.

\section{Method}

Multilevel mixed design, one of the mixed methods, has been used since the study aims to develop a scale to measure co-constructionist environment in the $7^{\text {th }}$ and $8^{\text {th }}$ Grade Science courses. As the study aims to develop a scale for Science courses, $7^{\text {th }}$ and $8^{\text {th }}$ Grade students' opinions about the co-constructionist environment of Science courses will be more suitable since they have been learning science for one or two years at the secondary education level. Multilevel mixed designs can be either parallel or sequential designs. In these designs, mixing happens through multiple levels of analysis, as quantitative or qualitative data are analyzed and combined to answer related aspects of the same research question or related questions (Teddlie \& Tashakkori, 2009, p. 136). In this study, literature research and interviews were carried out before writing the items of the scale. In this respect, a parallel design was used while collecting data from literature and interviews. Quantitative data were collected for factor analysis, and interview questions were created from the scale in terms of the related aspects of the same research to enhance the validity and reliability of the scale.

\section{Participants}

The study group of this research, who attended the pilot test, consists of 136 females $(57.1 \%)$ and 102 males $(42.9 \%)$, a total of 238 students studying at three different secondary schools in Afyonkarahisar. 137 of the students are $7^{\text {th }}$ Grade students, and 101 of them are $8^{\text {th }}$ grade students. The sampling method and the features of samples used are given in Table 1. 
Table 1

Sampling Method and Samples

\begin{tabular}{|c|c|c|}
\hline Data Collection Tool & Sampling Method & Samples \\
\hline Interview Form & Convenience Sampling & $\begin{array}{c}5 \text { secondary school students ( } 7^{\text {th }} \\
\text { and } 8^{\text {th }} \text { Grades) }\end{array}$ \\
\hline Literature research & Convenience Sampling & Books and articles \\
\hline $\begin{array}{l}\text { Pre-test application } \\
\text { (for item comprehensibility) }\end{array}$ & Convenience Sampling & $\begin{array}{c}10 \text { secondary school students } \\
\left(7^{\text {th }} \text { and } 8^{\text {th }} \text { Grades }\right)\end{array}$ \\
\hline $\begin{array}{l}\text { Pilot test application } \\
\text { (for item analysis) }\end{array}$ & Convenience Sampling & $\begin{array}{c}238 \text { secondary school students } \\
\left.\text { ( } 7^{\text {th }} \text { and } 8^{\text {th }} \text { Grades }\right)\end{array}$ \\
\hline Structured interview questions & Convenience Sampling & $127^{\text {th }}$ Grade students \\
\hline Test re-test reliability & Convenience Sampling & $\begin{array}{l}68 \text { secondary school students } \\
\left.\text { ( } 7^{\text {th }} \text { and } 8^{\text {th }} \text { Grades }\right)\end{array}$ \\
\hline
\end{tabular}

According to Table 1, secondary school students were asked open-ended questions about co-constructivism related to Science courses to create the item pool. Open-ended questions were asked to five students studying in $7^{\text {th }}$ or $8^{\text {th }}$ Grade. Secondly, the literature on co-constructivism was reviewed to write items related to the scale. The theoretical background about co-constructivism was obtained from the sources, and key concepts have been determined. After creating the item pool, ten secondary school students gave feedback on the comprehensibility of the items. After making necessary corrections, the 47 -item scale was applied to $2387^{\text {th }}$ and $8^{\text {th }}$ grade students in three different secondary schools in Afyonkarahisar in the first term of 20172018. To strengthen the validity and reliability of the scale, interview questions were prepared in line with the factor analysis findings, and they are asked to twelve $7^{\text {th }}$ grade students.

\section{Ethical Procedures}

Ethical approval and written permission were obtained from the Social and Humanities Scientific Research and Publication Ethics Board of Afyon Kocatepe University in Turkey with the decision dated 22.02.2021 and numbered 2021/111. Ethical rules were followed at each stage of the research. The participants took part in the study voluntarily.

\section{Findings}

\section{Development of the Scale}

This scale, which was developed to evaluate the co-constructivist environment in the Science courses, is 5 point Likert type. Likert-type scales are developed by using the item analysis approach. A particular item is evaluated in the item analysis approach based on the differences between high and low score items. Items that best meet such a difference test are included in the final measurement tool. Thus, Likert-type scales contain many sentences expressed from the most positive to the most negative attitude towards the given subject (Kothari, 2004, p. 84). According to the suggestions of 
Carpenter (2018) with regard to the development of a scale, the steps below were followed:

\section{Theory and Research}

The structure and meaning of a construct should be pre-specified by theory. According to the literature review and conceptual definitions, researchers analyzed the items of each factor to determine the most suitable concept label such as co-design, cowork, collaboration, culture sharing, interaction, common knowledge, relationship with real life. Potential dimensions and items were determined by considering the objectives of the $6^{\text {th }}$ and $7^{\text {th }}$ Grade Science curriculum. To create and validate items, researchers conducted a qualitative study. Through interviews, secondary school students about the activities related to co-constructivism were asked open-ended questions related to Science courses. An item pool consisting of 47 items was created for this scale. Twentysix of them included the objectives of the $7^{\text {th }}$ Grade curriculum. Four of them included the objectives of the $6^{\text {th }}$ Grade curriculum. Seventeen of them were created through the common subjects of the $6^{\text {th }}$ and $7^{\text {th }}$ Grade curriculum. The item pool was created considering the interaction and relationship between student and student, one of the coconstructivism dimensions. The other dimensions are the relationship between mother and child or student and teacher or learning in teams. Each item was written depending upon the literature and the 6th and 7th grade Science curriculum objectives. $6^{\text {th }}$ Grade Science curriculum covers the subjects as follows: Solar system and eclipse, systems and health in our body, force and motion, matter and heat, sound and features, conduction of electricity whereas $7^{\text {th }}$ Grade Science curriculum covers the subjects such as Solar system and beyond, cells and divisions, force and energy, pure substance and mixtures, the interaction of light with matter, reproduction, growth, and development in living things, electrical circuits. The items in the scale were tried to written considering each subject in the curriculums. Open-ended questions were asked to five students studying in $7^{\text {th }}$ or $8^{\text {th }}$ Grade.

Interviews and expert feedback are critical in the item generation and dimension identification process. Expert feedback was used for item refinement to eliminate complex wording/language and vagueness in questions/biased questions. After the item pool was created, 59 items were evaluated by three experts to have their opinions. These experts examined the items whether they were written according to the objectives stated in the Science curriculum. 11 items that were not suitable for the $6^{\text {th }}$ and $7^{\text {th }}$ Grade Science curriculum were removed from the scale, and six misunderstood items were corrected. Items were marked as "I always do" (5 points), "I often do" (4 points), "I occasionally do" (3 points), "I rarely do" ( 2 points), and "I never do" (1 point). The high score obtained from the scale indicated that the respondent agrees with the items. In other words, getting a high score from the scale indicated that the participant agrees that a co-constructivist environment exists in Science courses, while getting a low score means the opposite of this view.

To refine questionnaire questions and the design of the scale, a pre-test was applied to a group of ten secondary school students to identify problems in terms of language and expression. After this pre-test, one unsuitable item was removed from the scale. Then, the remaining items were checked for content validity, showing a basis for 
the literature, and the scale was applied to $2387^{\text {th }}$ and $8^{\text {th }}$ Grade students in three different secondary schools in Afyonkarahisar for pilot testing.

\section{Determine Sampling Procedure}

In this step, researchers decided on an appropriate sample size. Gorsuch (1983) states the required sample size for factor analysis as follows: "The minimum ratio is 5 individuals for each variable" (Thompson, 2004, p. 24). The sample size in this study is suitable for factor analysis $(n=238)$.

\section{Examine Data Quality}

Researchers checked for missing data and deleted a few cases since most responses contained missing data or only the same answer.

\section{Verify the Factorability of the Data}

Bartlett test is the most useful way to determine whether variances are equal (Singh, 2007, p. 102). Kaiser-Meyer-Olkin (KMO) coefficient and Barlett sphericity test were used to determine the suitability of the data for factor analysis (Büyüköztürk, 2012, p. 126). Accordingly, the KMO result of the items being .95 and Barlett test value being .00 significant $\left(x^{2}=7886 ; s d=1081 ; p<.01\right)$ showed that the data were suitable for factor analysis. If $\mathrm{KMO}$ is higher than .70, it indicated that a sufficient number of samples were available for each factor (Leech et al., 2005, p. 80).

\section{Conduct Exploratory (Common) Factor Analysis}

Exploratory factor analysis was conducted to determine the construct validity of the scale. The findings of exploratory factor analysis were presented orally by the researchers (Ocak \& Hocaoglu, 2018a). Exploratory factor analysis aims to determine the number of common factors affecting a group of measures and the strength of the relationship between each observed measure and factor (DeCoster, 1998).

\section{Select Factor Extraction Method}

In this study, principal component analysis was used as a factoring technique to facilitate interpretation.

\section{Determine the Number of Factors}

To determine the factor number, eigenvalues greater than one rule were taken into account. Items with an Eigenvalue (initial eigenvalue) greater than 1.00 were included in the scale. As in Table 2, 5 factors explain $64.371 \%$ of the total variance. This value is above $41 \%$, which is the acceptable value (Kline, 1993). 
Table 2

Explanation of the Total Variance of the Co-constructivism Scale

\begin{tabular}{|c|c|c|c|c|c|c|c|c|c|}
\hline \multirow[b]{2}{*}{ Item } & \multicolumn{3}{|c|}{ Initial Eigenvalues } & \multicolumn{3}{|c|}{$\begin{array}{c}\text { Extraction Sums of Squared } \\
\text { Loadings }\end{array}$} & \multicolumn{3}{|c|}{$\begin{array}{c}\text { Rotation Sums of Squared } \\
\text { Loadings }\end{array}$} \\
\hline & Total & $\begin{array}{l}\text { Explained } \\
\text { Variance }\end{array}$ & $\begin{array}{c}\text { Total } \\
\text { Variance }\end{array}$ & Total & $\begin{array}{l}\text { Explained } \\
\text { Variance }\end{array}$ & $\begin{array}{l}\text { Total } \\
\text { Variance }\end{array}$ & Total & $\begin{array}{l}\text { Explained } \\
\text { Variance }\end{array}$ & $\begin{array}{l}\text { Total } \\
\text { Variance }\end{array}$ \\
\hline 1 & 11.857 & 43.914 & 43.914 & 11.857 & 43.914 & 43.914 & 4.092 & 15.156 & 15.156 \\
\hline 2 & 1.774 & 6.569 & 50.483 & 1.774 & 6.569 & 50.483 & 3.977 & 14.730 & 29.886 \\
\hline 3 & 1.392 & 5.157 & 55.640 & 1.392 & 5.157 & 55.640 & 3.668 & 13.587 & 43.473 \\
\hline 4 & 1.233 & 4.566 & 60.206 & 1.233 & 4.566 & 60.206 & 3.111 & 11.521 & 54.994 \\
\hline 5 & 1.125 & 4.165 & 64.371 & 1.125 & 4.165 & 64.371 & 2.532 & 9.377 & 64.371 \\
\hline 6 & .841 & 3.115 & 67.486 & & & & & & \\
\hline 7 & .816 & 3.023 & 70.509 & & & & & & \\
\hline 8 & .673 & 2.494 & 73.002 & & & & & & \\
\hline 9 & .646 & 2.392 & 75.394 & & & & & & \\
\hline 10 & .616 & 2.281 & 77.676 & & & & & & \\
\hline 11 & .585 & 2.168 & 79.844 & & & & & & \\
\hline 12 & .567 & 2.099 & 81.942 & & & & & & \\
\hline 13 & .493 & 1.825 & 83.767 & & & & & & \\
\hline 14 & .469 & 1.737 & 85.503 & & & & & & \\
\hline 15 & .451 & 1.671 & 87.174 & & & & & & \\
\hline 16 & .443 & 1.639 & 88.814 & & & & & & \\
\hline 17 & .394 & 1.459 & 90.273 & & & & & & \\
\hline 18 & .380 & 1.407 & 91.679 & & & & & & \\
\hline 19 & .355 & 1.316 & 92.996 & & & & & & \\
\hline 20 & .347 & 1.284 & 94.279 & & & & & & \\
\hline 21 & .297 & 1.099 & 95.379 & & & & & & \\
\hline 22 & .275 & 1.019 & 96.398 & & & & & & \\
\hline 23 & .248 & .918 & 97.315 & & & & & & \\
\hline 24 & .209 & .776 & 98.091 & & & & & & \\
\hline 25 & .191 & .706 & 98.797 & & & & & & \\
\hline 26 & .169 & .625 & 99.423 & & & & & & \\
\hline 27 & .156 & .577 & 100.000 & & & & & & \\
\hline
\end{tabular}


According to Table 2, the variance explained by the $1^{\text {st }}$ factor is $43.914 \%$; by the $2^{\text {nd }}$ factor is $6.569 \%$; by the $3^{\text {rd }}$ factor is $5.157 \%$; by the $4^{\text {th }}$ factor is $4.566 \%$ and by the $5^{\text {th }}$ factor is $4.165 \%$.

\section{Rotate Factors}

The rotation process was performed using the varimax method because the varimax method examines the columns of the factor loadings matrix to achieve a meaningful structure. This method also ensures that fewer variables make the most factor variances (Tavşancıl, 2010). In Table 3, the rotated components matrix belonging to the Co-constructivism scale is given.

Table 3

Rotated Components for the Co-constructivism Scale

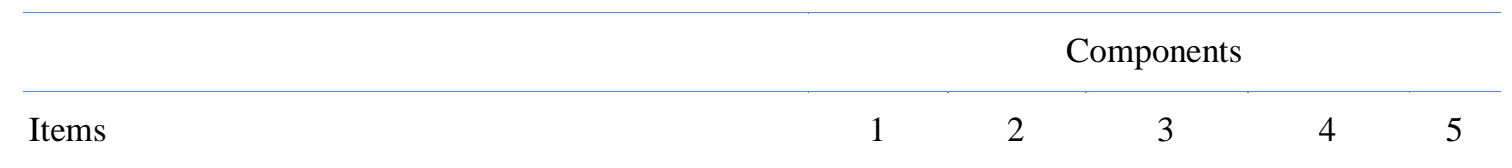

I prepare a project with my friends on the development of the chemical industry in Turkey.

I design a tool with my friends for reducing the effect of water resistance.

I design a tool with my friends for reducing the effect of air resistance.

I share with my friends local naming for organs given in different regions of Turkey.

I research with my friends the most frequent system diseases (circulatory system, digestive system, etc.), which are seen in different regions of Turkey.

I design an original lighting system with my friends.

I discuss with my friends about heat insulation of the buildings in terms of family and country economy.

I research with my friends the precautions related to the stove and natural gas poisoning.

I prepare a presentation with my friends on domestic and liquid waste.

I prepare a presentation with my friends on the importance of heat insulation of the buildings.

I prepare a presentation with my friends on the importance of social solidarity for organ donation.

I prepare a presentation with my friends on the importance of Green Crescent.

I discuss with my friends the effect of water resistance in real life. 
I discuss with my friends the effect of air resistance on the design of different vehicles.

.718

I discuss with my friends the effect of air resistance in real life.

I discuss with my friends the effect of water resistance on the design of different vehicles.

surrounding.

I discuss the examples I gave about kinetic energy with my friends.

I associate the relation between cell-tissue-organ-

system-organism with another topic in real life.

I discuss with my friends the relation between celltissue-organ-system-organism by giving examples from current issues.

I share with my friends the idioms about our culture on the concepts of mass and weight (e.g., comparing the

weight of $1 \mathrm{~kg}$ gold and $1 \mathrm{~kg}$ cotton)

I give examples of changing cell structures with the development of the microscope.

terms of the importance of social solidarity.

I give examples of non-recyclable items on the home waster.

I share with my friends examples of a homogeneous mixture.

I identify the factors affecting the dissolution rate by conducting an experiment with my friends.

In Table 3, the factor loads of 27 items in the scale vary between .46 and .82 .

\section{Retain and Delete Items Based on a Priori Criteria}

Factor loads less than .30 are considered low, while those higher than .40 are considered high (Leech et al., 2005, p. 83). Items whose factor loads are less than .40 have been considered to be omitted. However, since there is no factor load lower than .40 , the item cannot be removed with this method. The items should have a high load value in one factor and a low load value in the other. The difference between two high load values is expected to be at least .10 (Büyüköztürk, 2012, p. 124). In this study, this was also taken into account when determining the factors. Accordingly, 20 items (item $27,42,35,43,38,22,30,41,18,29,7,21,19,31,11,28,37,10,23$ and 9) were omitted. After the items were removed, the scale became a 5-factor and 27-item scale. 


\section{Present Results}

The Cronbach Alpha value of the scale is $\alpha=.950$. If this value is .70 or higher, it is an indicator that the test scores are reliable (Büyüköztürk, 2012, p. 171). The testretest reliability was also examined to see the reliability based on score stability over time with 68 participants. The result is $r=.932$. It can be said that the scale is reliable since the result is close to 1 .

According to Table 3, factors are named based on the content of the items. The $1^{\text {st }}$ factor was named "collaborative design". When the items included in the $1^{\text {st }}$ factor are examined, it is understood that two or more individuals came together to work collaboratively or solve problems. For example, when the items like "I prepare the project with my friends", "I design a tool with my friends", "I do a research with my friends" are taken into account, it is seen that students come together and try to solve the existing problem by combining their knowledge, skills and abilities and co-construct their knowledge. The concept of co-constructivism means that individuals solve a common problem together and establish mutual understanding. The $2^{\text {nd }}$ factor was named "collaborative work". The items in this factor are generally expressions such as "I prepare a presentation with my friends," which include group work and aim for students to learn together. For this reason, the $2^{\text {nd }}$ factor was named "collaborative work". The $3^{\text {rd }}$ factor was named "social experience and interaction". The items in this factor are related to the behaviors in environments that require more interaction and where students will experience sociality. Students' discussing a topic with other students requires interaction. The $4^{\text {th }}$ factor was named "sharing culture". The items in this factor are mostly related to giving examples of culture (example of the relationship among cell-tissue-organ-system-organism), cultural sharing (expressions about mass and weight), and explaining the situations caused by the culture (social importance of organ donation). The $5^{\text {th }}$ factor was named as "relating with real life". When the content of the items in this factor is examined, giving examples of recyclable or non-recyclable items causes students to connect with real life and find real examples.

In Table 4, the total correlation values of the items, item remainder correlation values, and t-test results of $27 \%$ lower and upper groups are given.

Table 4

Item Analysis of the Co-constructivism Scale (Validity-Reliability Results)

\begin{tabular}{cccccc}
\hline Items & $\begin{array}{c}\text { Varimax Factor } \\
\text { Load }\end{array}$ & $\begin{array}{c}\text { Item Total } \\
\text { Correlation }\end{array}$ & $\begin{array}{c}\text { Item Remainder } \\
\text { Correlation }\end{array}$ & $\begin{array}{c}\text { t-test results of } 27 \% \\
\text { lower and upper } \\
\text { groups }\end{array}$ & $p$ value \\
\hline Item36 & .697 & .602 & .636 & 10.409 & .000 \\
Item17 & .689 & .646 & .678 & 12.508 & .000 \\
Item16 & .689 & .665 & .695 & 12.553 & .000 \\
Item33 & .650 & .675 & .705 & 13.955 & .000 \\
Item32 & .600 & .676 & .706 & 12.293 & .000 \\
Item34 & .595 & .614 & .649 & 12.686 & .000
\end{tabular}




\begin{tabular}{|c|c|c|c|c|c|}
\hline Item 45 & .741 & .628 & .662 & 13.418 & .000 \\
\hline Item46 & .740 & .633 & .667 & 13.402 & .000 \\
\hline Item47 & .686 & .672 & .702 & 13.645 & .000 \\
\hline Item44 & .684 & .711 & .738 & 15.526 & .000 \\
\hline Item 40 & .632 & .741 & .765 & 18.463 & .000 \\
\hline Item39 & .603 & .691 & .721 & 16.721 & .000 \\
\hline Item 13 & .742 & .642 & .674 & 12.628 & .000 \\
\hline Item14 & .718 & .644 & .676 & 11.354 & .000 \\
\hline Item 12 & .711 & .646 & .678 & 11.730 & .000 \\
\hline Item 15 & .678 & .688 & .718 & 15.082 & .000 \\
\hline Item6 & .613 & .578 & .614 & 10.708 & .000 \\
\hline Item8 & .466 & .585 & .622 & 10.305 & .000 \\
\hline Item4 & .766 & .410 & .456 & 7.063 & .000 \\
\hline Item5 & .716 & .577 & .614 & 10.616 & .000 \\
\hline Item3 & .676 & .575 & .611 & 10.826 & .000 \\
\hline Item2 & .611 & .613 & .647 & 12.060 & .000 \\
\hline Item1 & .564 & .566 & .603 & 10.476 & .000 \\
\hline Item 25 & .827 & .594 & .631 & 11.148 & .000 \\
\hline Item 26 & .750 & .612 & .648 & 11.910 & .000 \\
\hline Item 20 & .584 & .602 & .637 & 11.091 & .000 \\
\hline Item 24 & .463 & .632 & .664 & 11.684 & .000 \\
\hline
\end{tabular}

According to Table 4, item-total correlation values are between .410 and .741, and item remainder correlation values are between .456 and .765. Accordingly, it is possible to say that the items are good items since the item-total correlation coefficient r>.30 (Büyüköztürk, 2012, p. 171). Another way of item analysis is comparing the average scores given to each item by the extreme groups (upper group-lower group) (Tavşanc1l, 2010, p. 55). The differences between the item average scores of the lower $27 \%$ and upper $27 \%$ groups created according to the total scores of the test were found to be significant $(p<.01)$. This shows that the test has internal consistency (Büyüköztürk, 2012, p. 171).

In Table 5, means, standard deviation, and correlations coefficients of the subfactors of the Co-constructivism Scale are given. 
Table 5

Means, Standard Deviation and Correlations Coefficients of the Sub-factors

\begin{tabular}{cccccccccc}
\hline Factor & $N$ & $\bar{X}$ & $S D$ & $p$ value & $1^{\text {st }}$ & $2^{\text {nd }}$ & $3^{\text {rd }}$ & $4^{\text {th }}$ & $5^{\text {th }}$ \\
\hline $1^{\text {st }}$ Factor & 238 & 13.74 & 6.28 & .000 & 1 & .714 & .653 & .561 & .638 \\
$2^{\text {nd }}$ Factor & 238 & 15.02 & 6.65 & .000 & .714 & 1 & .632 & .564 & .660 \\
$3^{\text {rd }}$ Factor & 238 & 16.67 & 6.31 & .000 & .653 & .632 & 1 & .624 & .611 \\
$4^{\text {th }}$ Factor & 238 & 14.42 & 5.04 & .000 & .561 & .564 & .624 & 1 & .530 \\
$5^{\text {th }}$ Factor & 238 & 10.64 & 4.37 & .000 & .638 & .660 & .611 & .530 & 1 \\
\hline
\end{tabular}

According to Table 5, it is observed that there is a significant and moderate relationship between the factors. The correlation coefficient being between .70-1.00 indicates a high-level relationship; .70-.30 indicates a medium relationship, and .30-.00 indicates a low-level relationship (Büyüköztürk, 2012, p. 32). In Table 6, the alpha coefficients of the sub-factors of the co-constructivism scale are given.

Table 6

Internal Consistency Coefficients of Sub-Factors of the Co-constructivism Scale

\begin{tabular}{llc}
\multicolumn{1}{c}{ Factors } & Alpha \\
\hline 1. Collaborative Design & .850 \\
2. Collaborative Work & .852 \\
3. Social Experience and Interaction & .856 \\
4. Sharing Culture & .874 \\
5. Relating with Real Life & .868 \\
\hline
\end{tabular}

According to Table 6 , the alpha coefficient of the $1^{\text {st }}$ factor is .850 ; the alpha coefficient of the $2^{\text {nd }}$ factor is .852 ; the alpha coefficient of the $3^{\text {rd }}$ factor is .856 ; the alpha coefficient of the $4^{\text {th }}$ factor is .874 , and the alpha coefficient of the $5^{\text {th }}$ factor is .868 .

\section{Confirmatory Factor Analysis}

Confirmatory factor analysis (CFA) is performed to test hypotheses or validate theories about previously accepted factors (Urbina, 2004, p. 174). The items in the factor named as "co-design" are shown as a1-a6; the items in the factor named as "collaborative work" are shown as b1-b6; the items in the factor named as "social experience and interaction" are shown as c1-c6; the items in the factor named as "sharing culture" are shown as d1-d5, and the items in the factor named as "relating with real life" are shown as e1-e4. CFA was performed by considering the answers of 134 samples. The subscale and composite scale reliability of coefficients of this model tested with CFA was calculated. 


\section{Confirmatory Factor Analysis First Level}

The path diagram of the co-constructivism scale is given in Figure 2, and the $t$ values for the latent variables to explain the observed variables are shown on the arrows. According to Schermelleh-Engel et al. (2003), if t values exceed 2.58, it is significant at the .1 level. The parameter estimates of the co-constructivism scale are significant at the .01 level. The chi-square value is 606.38 , and the df value is 314 . Accordingly, $\chi^{2} / d f$ is 1.93 . The fact that this ratio is less than 3 in large samples indicates that the level of compliance is perfect (Kline, 2011). RMSEA value is .084, which is an acceptable value. Values less than .07 for RMSEA indicate a good fit level (Steiger, 2007).

When the error variances of the observed variables in Figure 2 were examined, it was seen that the error variances were at an acceptable level. The explanatory properties of the items with very high error variance decrease at that rate (Çapık, 2014). In this case, even the items with the highest error variance (.92) were included in the analysis (Kline, 2011).

Figure 2

Error Variances in the Path Diagram of the Co-Constructivism Scale $1^{\text {st }}$ Level

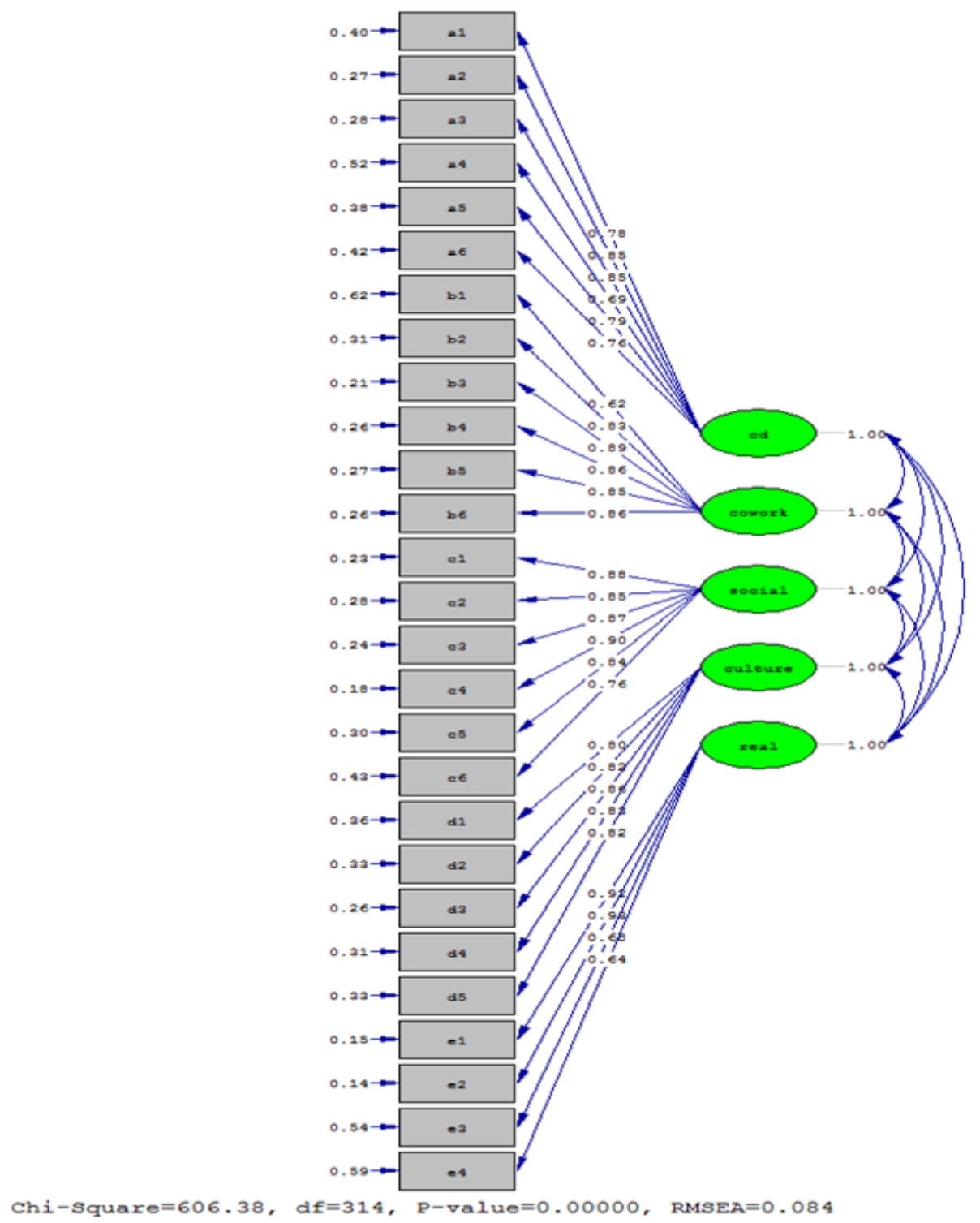


Table 7

The Goodness of Fit Indexes of the Co-constructivism Scale according to the Structural Model

\begin{tabular}{lccc}
\hline \multicolumn{1}{c}{ Goodness of fit indexes } & $\begin{array}{c}\text { Values of Co- } \\
\text { constructivism Scale }\end{array}$ & Perfect fit values & Acceptable fit values \\
\hline$\chi 2 / d f$ & 1.93 & $0 \leq \chi 2 / d f \leq 2$ & $2<\chi^{2} / \mathrm{df} \leq 3$ \\
RMSEA & .084 & $0 \leq \mathrm{RMSEA} \leq .05$ & $.05<\mathrm{RMSEA} \leq .08$ \\
Comparative Fit Index (CFI) & .91 & $.97 \leq \mathrm{CFI} \leq 1.00$ & $.95 \leq \mathrm{CFI}<.97$ \\
Standardized RMR & .064 & $0 \leq \mathrm{SRMR} \leq .05$ & $.05<\mathrm{SRMR} \leq .10$ \\
Goodness of Fit Index (GFI) & .75 & $.95 \leq \mathrm{GFI} \leq 1.00$ & $.90 \leq \mathrm{GFI}<.95$ \\
Adjusted Goodness of Fit & .70 & $.90 \leq \mathrm{AGFI} \leq 1.00$ & $.85 \leq \mathrm{AGFI}<.90$ \\
Index (AGFI) & & & $.95 \leq \mathrm{NNFI}<.97$ \\
NNFI & .90 & $.97 \leq \mathrm{NNFI} \leq 1.00$ & \\
\hline
\end{tabular}

According to Table $7, \chi^{2} / d f$ ratio is 1.93 . This demonstrates the value of a good fit. If this ratio is less than 3 , it shows that the level of compliance is perfect (Kline, 2011). RMSEA value is .084. Brown (2015) recommends that the RMSEA value should be close to or less than .06. Accordingly, the RMSEA value is at an acceptable level. The value of CFI is .91. If this value is greater than .90 , the model has an acceptable level of good fit (Kline, 2011). The value of SRMR is .064. According to Table 7, this value is also acceptable goodness of fit. GFI, AGFI, and NNFI values are seen to have poor fit according to the goodness of fit index. Although not all indexes show perfect results, the ratio of $\chi^{2 / d f}$ and RMSEA value are among the goodness of fit index. Accordingly, these findings confirm the factor structure of the co-constructivism scale. In Figure 3, error variances of the $2^{\text {nd }}$ level of the co-constructivism scale in the path diagram are given.

When the error variances of the observed variables in Figure 3 were examined, it was seen that the error variances were at an acceptable level. The explanatory properties of the items with very high error variance decrease at that rate (Çapık, 2014). In this case, even the items with the highest error variance (0.93) were included in the analysis (Kline, 2011). 
Figure 3

Error Variances in the Path Diagram of the Co-constructivism Scale $2^{\text {nd }}$ Level

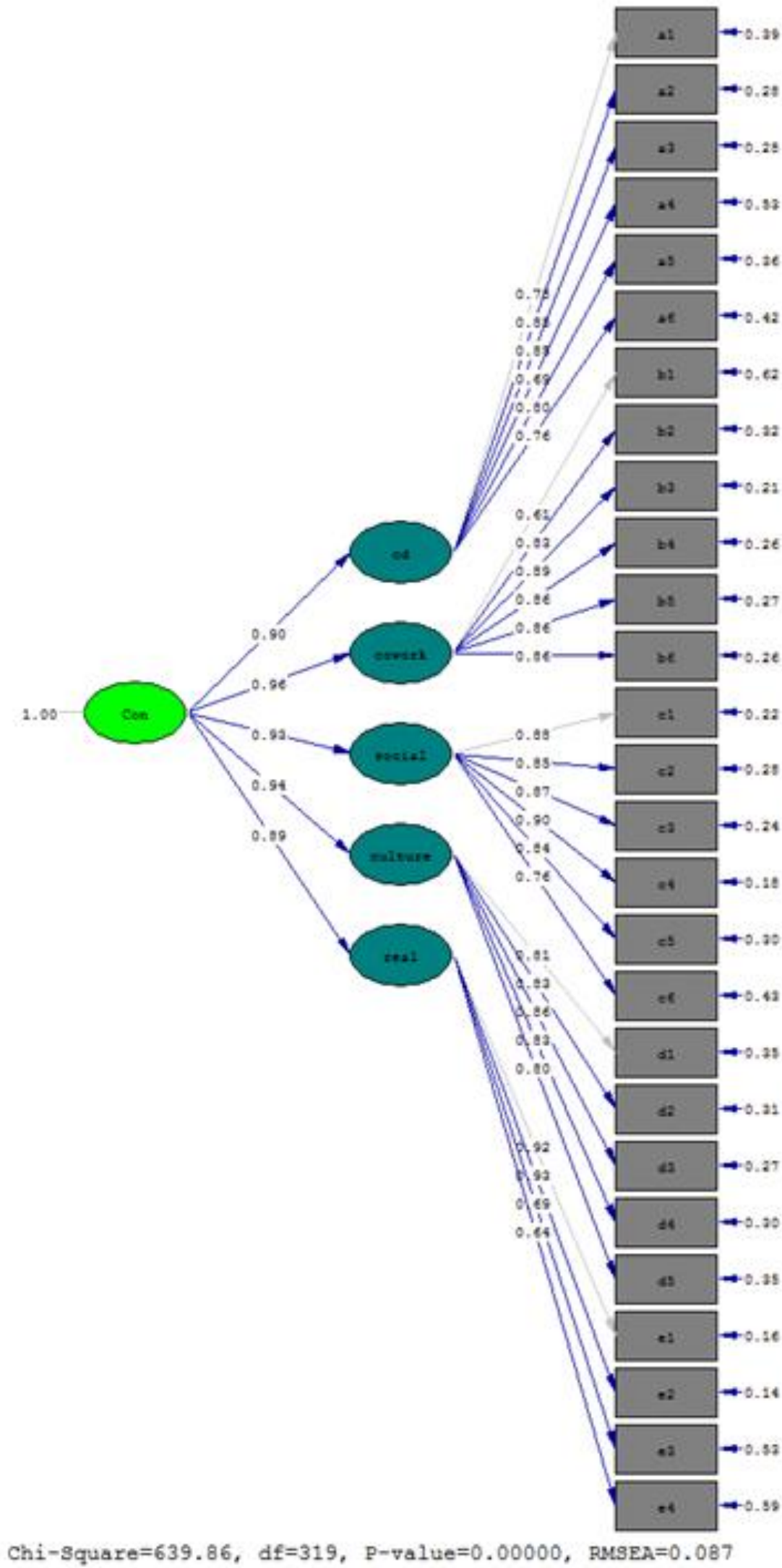

In Table 8, the scale development process is given in brief. 
Table 8

Development of the Scale

Development of the Scale

1. Theory and Research

a. Conceptual Definitions

The most suitable concept labels such as co-design, co-work, collaboration, culture sharing, interaction, common knowledge, relationship with real life were identified.

b. Potential Dimensions

Potential dimensions and items were determined by considering the objectives of the $6^{\text {th }}$ and $7^{\text {th }}$ Grade Science curriculum. Through interviews, secondary school students were asked open-ended questions related to the activities related to co-constructivism.

c. Item Pool

An item pool consisting of 47 items was created for this scale. 26 of them included the objectives of the $7^{\text {th }}$ Grade curriculum. 4 of them included the objectives of the $6^{\text {th }}$ Grade curriculum. 17 of them were created through the common subjects of $6^{\text {th }}$ and $7^{\text {th }}$ Grade curriculum.

d. Interviews and Expert Feedback

Open-ended questions were asked to five students studying in $7^{\text {th }}$ or $8^{\text {th }}$ Grade. The answers given to these questions guided the researchers while writing the items of the scale. After the item pool was created, 59 items were evaluated by three experts to have their opinions. 11 items that were not suitable for the $6^{\text {th }}$ and $7^{\text {th }}$ Grade Science curriculum were removed from the scale and six misunderstood items were corrected.

e. Pre-test application

A pre-test was applied to a group of ten secondary school students to identify problems in terms of language and expression. After this pre-test, one unsuitable item was removed from the scale. The remaining items were checked in terms of content validity, showing a basis for the literature, and the scale was applied to $2387^{\text {th }}$ and $8^{\text {th }}$ Grade students in three different secondary schools in Afyonkarahisar for pilot testing.

2. Determine Sampling Procedure

The sample size in this study is suitable for factor analysis $(n=238)$.

3. Examine Data Quality

Researchers checked for missing data and deleted a few cases since most responses contained missing data or only the same answer.

4. Verify the factorability of the data

The KMO result of the items being .95 and Barlett test value being .00 significant $\left(x^{2}=7886\right.$; $s d=1081 ; p<.01$ ) showed that the data were suitable for factor analysis.

5. Conduct exploratory (common) factor analysis

Exploratory factor analysis was conducted.

6. Select factor extraction method

Principal component analysis was used as a factoring technique to facilitate interpretation.

7. Determine the number of factors 
Eigenvalues greater than one rule was taken into account.

8. Rotate factors

The rotation process was performed using the varimax method.

9. Retain and delete items based on a priori criteria

The difference between two high load values is expected to be at least .10 (Büyüköztürk, 2012, p. 124). Accordingly, 20 items were omitted.

10. Present results

The Cronbach Alpha value of the scale is $\alpha=.950$. The test-retest reliability was also examined to see the reliability based on score stability over time with 68 participants. The result is $r=.932$. Item-total correlation values are between .410 and .741 , and item remainder correlation values are between .456 and .765 . The differences between the item average scores of the lower $27 \%$ and upper $27 \%$ groups created according to the total scores of the test were found to be significant $(p<.01)$. Factors are named based on the content of the items they contain. The alpha coefficient of each factor has been calculated.

11. Confirmatory Factor Analysis (CFA)

CFA was performed by considering the answers of 134 samples. The parameter estimates of the co-constructivism scale are significant at the .01 level. The chi-square value is 606.38 , and the $\mathrm{df}$ value is 314 . Accordingly, $\chi^{2} / d f$ is 1.93 . RMSEA value is .084 , which is an acceptable value.

\section{Interview Questions}

Criterion-related validity determines how well a test score may be used to infer an individual's most likely position on a measure of interest - the criterion being the measure of interest (Cohen \& Swerdlik, 2009, p. 180). The validity of the test content shows to what extent the items or questions in the data collection tool represent the appropriate universe or content area. This validity requires experts to examine the tool's content (McMillan \& Schumacher, 2001, p. 239-242). In this respect, a relationship may arise between the sub-factors of the scale and the interview questions. Thus, a qualitative study was conducted to increase the validity of the scale called "Coconstructivism" at Science courses.

For this reason, to support the quantitative findings previously obtained with qualitative findings, interviews were conducted with $7^{\text {th }}$ Grade students regarding coconstructivism in Science courses. Interviews were conducted with twelve secondary school students selected with appropriate sampling method using a structured interview form consisting of eight questions under five main headings compromisingly with the five sub-factors of the scale. At this stage, it was aimed to measure the consistency of the answers given by the students for the "Co-constructivism" scale through interviewing them over the general theme of the sub-factors. At the same time, it was intended to determine how well the scale measures the desired situation and obtain a general framework by gaining from the students' experiences whether the applications of co-constructivism theory have been put into practice in Science courses.

Descriptive analysis was used to analyze the data. The five main questions prepared for the interviews were accepted as five main themes. Students' views were analyzed and interpreted in line with these themes. Each main part in the interview form was considered as the main theme. The answers of the students were typed and coded under the main themes. Then, researchers determined the similarities and differences of the codes and made thematic coding by bringing together the codes related to each 
other. Thus, the main themes and sub-themes under them were revealed. Codes were organized under sub-themes. The following steps were followed to create the questions in the structured interview form:

To examine in detail the crucial findings that emerged in the analysis of quantitative data, the questions in the interview form were created.

- After the questions were formed, expert opinion was received from two experts to determine the correctness of the questions in terms of language and expression.

- The questions have been reshaped according to the suggestions of the experts.

- Five students were interviewed to determine the comprehensibility of the questions as a pre-application.

- Accordingly, any misunderstandings were corrected, and it was recorded how long the students' answering of the questions would take.

- After pre-application, the interview questions took their final form.

- The structured interview form consists of 8 open-ended questions forming five sub-themes. These five sub-themes reflect the sub-dimensions in the scale, and the questions are related to these sub-dimensions.

To ensure the reliability of the study, it was worked with a co-observer other than the researchers. Co-observer is a faculty member who has qualitative studies at the Department of Curriculum and Instruction. The co-observer was asked which theme and sub-theme each code belonged to for the themes and categories that emerged. The frequency and percentage values that the researchers and co-observer made for the coding were calculated to obtain the consensus agreement between the researchers and co-observer. In qualitative studies, it is a reliable method to encode more than one person and control the coding by another person (Miles \& Huberman, 1994, p. 64). Miles and Huberman's (1994) reliability formula (Reliability $=$ [Consensus / (Consensus + Disagreement)] x 100) was used to determine the agreement between the researchers' and co-observer's analyses, and the result was calculated as $88 \%$.

One of the criteria of validity in qualitative research is reporting the data in detail and explaining how the researcher reached the results (Yıldırım \& Şimşek, 2013). To ensure the validity of the study, it was reported in detail how the data collection tool was formed, how the data were collected and reported, and how the results were reached. In addition, students' answers for each theme and sub-themes are provided as examples.

In the first sub-question of the first question, the students were asked whether they designed a vehicle with their friends in the Science course and how effective their thoughts were in this design. In the other sub-question of the first question, the students were asked whether they prepared a project with their friends in the Science course and how the task sharing was done among them. The findings obtained regarding these questions are given in Table 8, together with their frequencies. In addition, sample answers for each sub-theme are given below. 
Table 8

Students' Views on the Questions in the Main Theme of "Co-constructivism"

\begin{tabular}{llr}
\hline \multicolumn{1}{c}{ Sub-themes } & \multicolumn{1}{c}{ Main Theme: Collaborative design } & \multicolumn{1}{c}{ Codes } \\
\hline Vehicle Design & \multicolumn{1}{c}{ Lack of application (S1, S2, S4, S7, S10, S11, S12) } & 7 \\
& Individual study (S3, S5, S9) & 3 \\
& Influence of the student's ideas (S6, S8) & 2 \\
& Joint decision (S6, S8) & 2 \\
\hline Project Preparation & Lack of application (S3, S5, S6, S7, S8, S10, S11) & 2 \\
& The project's being elective (S9, S12) & 2 \\
& Task sharing (S2, S4) & 1
\end{tabular}

The students were asked questions about "vehicle design" and "project preparation", which are sub-themes, under the main theme of "co-constructivism". According to the "vehicle design" sub-theme, most students $(f=10)$ stated that they did not design a vehicle with their friends. Three of them said that they designed a vehicle individually. The answers given by the students are as follows:

S11: "I did not design a vehicle with my friends." (lack of application)

S3: "We made an electrical circuit. Everyone did it by him/herself." (individual study)

S6: "My thoughts were also influential while designing it, and also we made a joint decision." (Influence of the student's ideas and joint decision)

According to the "project preparation" sub-theme, most students $(f=9)$ stated that they did not prepare a project with their friends. Two of them stated that they did not prepare a project because they did not take a project assignment in the Science course. The answers given by the students are as follows:

S7: "We did not prepare a project." (lack of application)

S12: "I did not take part in a project because it was elective." (the project's being elective)

S4: "Task sharing was made in the procurement of the materials. Also, one of us poured the mineral water, the other shredded the biscuit. Our teacher gave these tasks to us." (task sharing)

In the first sub-question of the second question, the students were asked whether they took part in research with their friends in the Science course and contributed to them. In the other sub-question of the second question, the students were asked whether they prepared a presentation with their friends in the Science course and what they learned from their friends if they prepared a presentation. The findings obtained regarding these questions are given in Table 9 together with their frequencies: 
Table 9

Students' views on the questions in the main theme of "collaborative work"

\begin{tabular}{llr}
\hline \multicolumn{1}{c}{ Sub-themes } & \multicolumn{1}{c}{ Main Theme: Collaborative work } & \multicolumn{1}{c}{ Codes } \\
\hline $\begin{array}{l}\text { Research and } \\
\text { Contributions }\end{array}$ & Lack of application (S2, S3, S4, S5, S8, S9, S11) & 7 \\
& Different ideas (S6, S12) & 2 \\
& Success (S1) & 1 \\
& Permanence (S1) & 1 \\
& Correction of mistakes (S6) & 1 \\
& Resource support (S7) & 1 \\
& Participation (S10) & 1 \\
& Completing the deficiencies (S12) & 10 \\
& Lack of application (S1, S3, S5, S6, S7, S8, S9, S10, S11, S12) & 2 \\
\hline Presentation Preparation & New knowledge (S2, S4) & \\
\hline
\end{tabular}

Under the main theme of "collaborative work", the students were asked questions about the sub-themes of doing research and its contributions and preparing presentations. According to the sub-theme of research and contributions, more than half of the students $(f=7)$ stated that they did not research with their friends. Students who researched with their friends stated that they learned different ideas the most $(f=2)$. The answers given by the students are as follows:

S8: "We did not research with friends." (lack of application)

S6: "I took part in a research. I learned different ideas and my friends corrected my mistakes." (different ideas and correction of mistakes)

S1: "We did a research about life and discoveries of a scientist. What I learned through working cooperatively became more permanent since I remembered them in the exam. And I passed the exam." (success and permanence)

According to the sub-theme of preparing a presentation, most of the students $(f=10)$ stated that they did not prepare a presentation with their friends in the Science course. The answers given by the students are as follows:

S12: "I did not prepare any presentation with my friends." (lack of application)

In the third question, the students were asked what effect their participation in class discussions in the Science course had on their learning. The findings related to this question are given in Table 10. 
Table 10

Students' Views on the Questions in the Main Theme of "Social Experience and Interaction"

Main Theme: Social experience and interaction

\begin{tabular}{llc}
\multicolumn{1}{c}{ Sub-themes } & \multicolumn{1}{c}{ Codes } & $f$ \\
\hline Positive & New knowledge (S1, S3, S6, S9, S11) & 5 \\
& Better comprehension (S3, S5, S9) & 3 \\
& Fast learning (S1) & 1 \\
& A different point of view (S4) & 1 \\
& Correction of mistakes (S8) & 2 \\
\hline Lack of application & No class discussions (S2, S12) & 2 \\
\hline Neutral & No effect (S7, S10)
\end{tabular}

Under the main theme of "social experience and interaction", the students were asked about the effects of classroom discussions on learning. Most of the answers are positive $(f=11)$. Two of the students stated that they did not discuss in the classroom, while the other two stated that the discussions did not affect learning. The answers given by the students are as follows:

S1: "I learn different and new information from my friends." (new knowledge)

S5: "The more my friends give examples, the better I understand the subject." (better comprehension)

S2: "There is no discussion in the classroom." (no class discussions)

S10: "Some discussions are not effective." (no effect)

In the fourth question, the students were asked which examples of our culture related to the subject they covered in the Science course. The findings were given in Table 11.

Table 11

Students" views on the questions in the main theme of "sharing culture"

\begin{tabular}{llc}
\hline \multicolumn{1}{c}{ Main Theme: Sharing culture } & \multicolumn{1}{c}{ Codes } & $f$ \\
\hline \multicolumn{1}{c}{ Sub-themes } & \multicolumn{1}{c}{} & 1 \\
\hline Existence of the application & Vegetables and fruits (S1) & 1 \\
& Elements (S2) & 1 \\
& Natural disasters (S11) & 9 \\
\hline Lack of application & Lack of examples (S3, S4, S5, S6, S7, S8, S9, S10, S12) & \\
\hline
\end{tabular}

Under the main theme of "sharing culture", the students were asked what examples they emphasized on the subject. Most of the students $(f=9)$ stated that examples of our culture were not given. The answers given by the students are as follows: 
S3: "I do not remember whether we gave any examples." (lack of examples)

S11: "Examples of natural disasters in Afyon were given." (natural disasters)

In the first sub-question of the fifth question, the students were asked about the effects of these real life examples on learning, and in the other sub-question, the effects of experiments on learning were asked. The findings are given in Table 12.

Table 12

Students' Views on the Questions in the Main Theme of "Relating with Real Life"

\begin{tabular}{|c|c|c|}
\hline \multicolumn{3}{|c|}{ Main Theme: Relating with real life } \\
\hline Sub-themes & Codes & $f$ \\
\hline \multirow[t]{5}{*}{ The effects of examples from real life } & Facilitating of comprehension (S1, S6, S7, S8, S11, S12) & 6 \\
\hline & Transfer to real life $(\mathrm{S} 4, \mathrm{~S} 10)$ & 2 \\
\hline & Correction of mistakes (S3) & 1 \\
\hline & Positive effect (S2) & 1 \\
\hline & Permanence (S5) & 1 \\
\hline \multirow[t]{5}{*}{ The effects of experiments on learning } & Facilitating of learning (S3, S4, S8, S10, S11) & 6 \\
\hline & Permanence (S2, S5, S7, S12) & 4 \\
\hline & Positive Effect (S1, S9, S12) & 2 \\
\hline & Responsibility (S9) & 1 \\
\hline & Success (S10) & 1 \\
\hline
\end{tabular}

The biggest effect of real life examples was facilitating students' understanding of the subject $(f=6)$. The answers given by the students are as follows:

S8: "I learn the subject better with examples. When the teacher asks what the subject is, I think of examples first, not the subject. Considering the example, I also learn the explanation of the subject". (facilitating of comprehension)

S10: "We gave examples of the mixture of tea, water, and soil. I told my mother whether the ingredients in the meals are homogeneous or heterogeneous". (transfer to real life)

The biggest effect of the experiments on learning was to facilitate learning $(f=6)$ and ensure the subject's permanence $(f=4)$, respectively. The answers given by the students are as follows:

S2: "When we do experiments, what I learn becomes more permanent." (permanence)

S10: "Participating in the experiments of the subjects, covered on the days when I wasn't attending school, at other times helped me learn those subjects. I learned through the experiment and got a high grade from the exam." (success) 


\section{Discussion and Conclusion}

This study aimed to develop a scale to measure the co-constructionist environment in the Science courses. As a result of the exploratory factor analysis, the scale has become a five-dimensional scale. Accordingly, the first factor (collaborative design) consists of 6 items and explains $43.914 \%$ of the total variance. The second factor (collaborative work) consists of 6 items and explains $6.569 \%$ of the total variance. The third factor (social experience and interaction) consists of 6 items and explains $5.157 \%$ of the total variance. The fourth factor (sharing culture) consists of 5 items and explains $4.566 \%$ of the total variance. Finally, the fifth factor (relating to real life) consists of 4 items and explains $4.165 \%$ of the total variance. Thus, the scale consisting of 27 items and five factors explains $64.371 \%$ of the total variance. While the Cronbach Alpha coefficient of the scale is .950, the Alpha coefficients of the factors are as follows; .850, 852, .856, .874, and .868. Accordingly, the scale shows internal consistency with its factors. Item total, item remainder, and item discrimination indexes were examined for each item. In the item discrimination analysis, the difference between the item average scores of the lower 27\% and upper 27\% groups formed according to the total scores of the test was analyzed through an independent sample ttest, and the difference was found to be significant $(p<.01)$. In line with these findings, the validity of the items on the scale is high. Confirmatory factor analysis was conducted to obtain the accuracy of the factors obtained from the exploratory factor analysis, and the confirmatory factor analysis results confirm the factor structure. Therefore, the developed scale can be used to measure the co-constructivist environment in the Science courses. The factor structure obtained from the exploratory factor analysis was confirmed by the confirmatory factor analysis results (RMSEA=.084; AGFI=.70; SRMR=.064; CFI=.91; NNFI=.90, $\chi^{2} / d f=1.93$ ). Moreover, items created after literature research were verified statistically.

The scale consists of five sub-factors: "collaborative design", "collaborative work", "social experience and interaction", "sharing culture," and "relating with real life". The content of these sub-factors is in line with the concepts of co-constructivism as they are suggested as the main points of social constructivism in the study of Eastwell (2002). According to the "collaborative design" sub-factor items, students are expected to structure their knowledge and design new products together. The developing person is an active and constructive individual in a collective culture (Lyra \& Valsiner, 1998, p. 187). While designing a new product or preparing a project with his/her friends, he/she establishes a dynamic relationship with others. Knowledge does not occur in the student alone but is formed by structuring with others (Reusser, 2001). Since the 6th and 7th Grade curriculum subjects such as force, motion and energy; conduction of electricity and electrical circuits; light and matter are suitable for designing a tool, co-constructivism serves well for this aim of Science courses.

The second sub-factor, named "collaborative work," consists of the activities that students come together and do. Co-constructivism requires collaborative compromise. Two or more people are expected to come together and work collaboratively to build a common understanding (Reusser, 2001). In their scale development study, Johnson and McClure (2004) found five sub-factors to determine the constructivism environment. These are personal fitness, student compromise, joint control, critical voice, and uncertainty. Among them, the closest concept to co- 
constructivism is student compromise. Cooperative learning lies at the heart of constructivism. Collaborative work is also one of the cornerstones of the theory of coconstructivism. In parallel with the study of Johnson and McClure (2004), "collaborative work" was found as one of the sub-factors forming the scale in this study. Conducting experiments in a school requires students to work in teams in a responsible and kind manner because students are able to share their ideas and discuss possible alternatives in a comfortable way. Co-constructivist environments make collaborative work possible in Science courses.

Items in the "social experience and interaction" sub-factor are generally composed of items that students come together and prepare a presentation. Students interact while preparing a presentation and collectively make a decision for each part of the presentation. Knowledge occurs between individuals who have common interactions and conventions. Social theory, called co-constructivism, covers peer interaction and higher-order thinking skills that vary according to the characteristics of social interaction (Reusser, 2001). Dialogue between students is a crucial variable of coconstructivism theory (Daws, 2005). Some studies in the field of Science (Marinopoulos \& Stavridou, 2008; Pilatou \& Stavridou, 2008) found that knowledge is structured in a social environment, and collaborative learning environments facilitate learning of Science courses. Strong engagement and active participation are significant features of co-constructivist theory. Through interaction with others, students will have different perspectives on issues related to science and technology as they share information with their peers. In this respect, this sub-factor of the Co-constructivism Scale in Science courses contributes to the objectives of Science teaching.

Items in the sub-factor named "sharing culture" include transferring culture to the classroom and exchanging culture with others. While structuring knowledge, the cultural field is structured together. Many learnings occur as a result of cultural sharing (Reusser, 2001). It is critical for science teachers to understand the fundamental, culturally-based worldviews that students bring to class and how culture supports these viewpoints. Science education is only successful if science can find a place in students' cognitive and cultural environments (Cobern, 1998). As the students have different cultural characteristics, they reflect different cultural aspects to the classroom, and teachers should benefit from these multicultural features of the students in a positive way. One of the ways to benefit from these cultural features is to blend culture sharing within the course activities. Applying the principles of co-constructivism facilitates culture sharing through social motivation, so the items in this sub-factor make it more concrete.

Items in the last sub-factor, "relating with real life" require giving examples from real life experience and conducting experiments. Through such activities, students relate their learning experiences to real life. Among the concepts that create coconstructivism, there is the relationship between learning experiences and real life (Reusser, 2001). For this reason, in a classroom in which a co-constructivist environment is provided, students should give real-life examples. Therefore, activities should be task-oriented, and the materials used and the types of assessment should be authentic. In Özgür's (2008) study, a scale was applied to students and teachers to determine the constructivist environment. One of the sub-factors is related to learning about life. It includes the item as "students can give interesting examples about science 
and technology in daily life, thanks to what they learn in the course". This aspect of Özgür's (2008) study overlaps with one of the findings of this study. The items in this sub-factor were aimed to make students associate them with real life by giving examples from the subjects they learned about science. Science teaching aims to make students relate what they learn to everyday contexts, so teachers should relate science subjects to real life to make sense in students' minds. Moreover, in a classroom where the co-constructivist approach is adopted, students may easily find themselves in reallife situations.

Structured interview forms have eight questions under five main topics: the subfactors of the previously developed scale (Ocak \& Hocaoglu, 2018a). According to the qualitative questions related to the sub-factor as "collaborative design" of the scale, students have stated that they rarely design an instrument and prepare a project with their friends. According to the data about the sub-factor as "collaborative work", students have indicated that they rarely research and prepare presentations with their friends. According to the question related to the sub-factor called "social experience and interaction", students have mentioned that whole-class debates positively affect their learning. According to the question related to the sub-factor as "sharing culture", many students have stated that examples about culture were not given. According to the questions about "relating with real life", students mentioned that they gave examples about real life, and these examples and the experiments have facilitated learning and understanding most. It has been found that the qualitative results of this study have been mostly overlapped with the quantitative results of the study by Ocak and Hocaoglu (2018b). Hereunder, it is possible to say that the validity and reliability of the scale called "Co-constructivism" at Science Lessons of secondary education, which was previously developed, has been ensured by the quantitative data, and the result is high.

The skills that Science courses want to develop in students (e.g., analytical thinking, entrepreneurship, communication, teamwork) are parallel with the main principles of co-constructivist learning. Therefore, if the teachers follow the principles of co-constructivism, science learning will be more meaningful and permanent for the students. This scale, "Co-constructivism" at Science Lessons of secondary education, is a beneficial tool for determining how well a school atmosphere adheres to a coconstructivist epistemology in terms of collaborative design, collaborative work, social experience and interaction, sharing culture, and relating Science subjects with real life.

\section{Implications}

The roles of teachers in a co-constructivist environment are to guide students and support them in engaging them in authentic and task-oriented, structured social interactions. The items in this scale are restricted to the objectives of the $6^{\text {th }}$ and $7^{\text {th }}$ Grade Science curriculum. Therefore, the objectives of Science curriculums at the secondary education level can be considered for further scale development studies. For further research, the environment of co-constructivism at Science courses can be examined in terms of the interaction and relationship between students and teachers.

\section{Acknowledgments}

This study is funded by Scientific Research Projects of Afyon Kocatepe University with Project number 18.KARIYER.92. 


\section{Statement of Responsibility}

All of the authors contributed to the study equally.

\section{References}

Ağbuba, B. (2010). Öğrencilere yönelik yapılandırmacı öğretim yaklaşımı ölçeği: Bir geçerlilik ve güvenirlilik çalışması. Spor Bilimleri Dergisi, 21(3), 103-109.

Arkün, S., \& Aşkar, P. (2010). Yapılandırmacı öğrenme ortamlarını değerlendirme ölçeğinin geliştirilmesi. Hacettepe Üniversitesi Eğitim Fakültesi Dergisi, 39, 32-43.

Bay, E., Kaya, İ. K., \& Gündoğdu, K. (2010). Demokratik yapılandırmacı öğrenme ortamı ölçeği geliştirilmesi, e-Journal of New World Sciences Academy, 5(2), 646664.

Branco, A. U., \& Valsiner, J. (1997). Changing methodologies: A Co-constructivist study of goal orientations in social interactions. Psychology and Developing Societies, 9(1), 35-64.

Brown, T. A. (2015). Confirmatory factor analysis for applied research (2. ed.). The Guilford Press.

Bukova-Güzel, E., \& Alkan, H. (2005). Yeniden yapılandırılan ilköğretim programı pilot uygulamasının değerlendirilmesi. Kuram ve Uygulamada Ĕgitim Bilimleri Dergisi, 5(2), 385-420.

Büyüköztürk, Ş. (2012). Sosyal bilimler için veri analizi el kitabı. Pegem Akademi Yayıncilik.

Çapık, C. (2014). Geçerlik ve güvenirlik çalışmalarında doğrulayıcı faktör analizinin kullanımı. Anadolu Hemşirelik ve Sağllk Bilimleri Dergisi, 17(3), 196-205.

Carpenter, S. (2018). Ten steps in scale development and reporting: A guide for researchers. Communication Methods and Measures, 12(1), 25-44. https://doi.org/10.1080/19312458.2017.1396583

Cobern, W. W. (1998). Science and a Social Constructivist View of Science Education. In Cobern W.W. (Ed.), Socio-Cultural perspectives on science education. Science \& technology education library (pp.7-23). Springer. https://doi.org/10.1007/97894-011-5224-2_2

Cohen, R. J., \& Swerdlik, M. (2009). Psychological testing and assessment: An Introduction to tests \& measurement. McGraw Hill.

Daws, J. E. (2005). Teachers and students as co-learners: Possibilities and problems. Journal of Educational Enquiry, 6(1), 110-125.

DeCoster, J. (1998). Overview of factor analysis. http://www.stat-help.com/factor.pdf

Eastwell, P. H. (2002). Social constructivism. The Science Education Review, 1(3), 8286.

Evrekli, E., İnel, D., Balım, A. G., \& Kesercioğlu, T. (2009). Fen öğretmen adaylarına yönelik yapılandırmacı yaklaşım tutum ölçeği: Geçerlilik ve güvenirlik çalışması. Türk Fen Eğitimi Dergisi, 6(2), 134-148.

Fer, S., \& Cirık, İ. (2010). Öğretmenlerde ve öğrencilerde, yapılandırmacı öğrenme ortamı ölçeğinin geçerlik ve güvenirlik çalışması nedir? Yeditepe Üniversitesi Ĕ̌itim Fakültesi Dergisi, 2(1), 1-27. 
Geert, P. V., Mos, L. P., \& Baker, W. J. (1994). Annals of theoretical psychology. Plenum Press.

Hyslop-Margison, E. J., \& Strobel, J. (2008). Constructivism and education: Misunderstandings and pedagogical implications. The Teacher Educator, 43, 72-86.

Johnson, B., \& McClure, R. (2004). Validity and reliability of a shortened, revised version of the Constructivist Learning Environment Survey (CLES). Learning Environments Research, 7(1), 65-80.

Jones, M. G., \& Brader-Araje, L. (2002). The impact of constructivism on education: Language, discourse, and meaning. American Communication Journal, 5(3), 1-10.

Kline, P. (1993). An easy guide to factor analysis. Routledge.

Kline, R. B. (2011). Principles and practice of structural equation modeling ( $\left.{ }^{\text {rd }} \mathrm{ed}.\right)$. The Guilford Press.

Kothari, C. R. (2004). Research methodology: Methods and techniques. New Age International.

Küçüközer, H., Kırtak Ad, V. N., Ayverdi, L., \& Eğdir, S. (2012). Yapılandırmac1 öğrenme ortamları ölçeğinin Türkçe’ye uyarlanması. İlköğretim Online, 11(3), 671688.

Leech, N. L., Barrett, K. C., \& Morgan, G. A. (2005). SPSS for intermediate statistics: Use and interpretation (2. ed.). Lawrence Erlbaum Associates.

Lyra, M. C. D. P., \& Valsiner, J. (1998). Construction of psychological processes in interpersonal communication. Ablex Publishing Corporation.

Marinopoulos, D., \& Stavridou, H. (2008). Improving primary school students' (11-12) understanding about water pollution. International Journal of Learning, 15(5), 143149.

Matthews, M. R. (1998). Constructivism in science education: A philosophical examination. Springer Science + Business Media, B. V.

McMillan, J. H., \& Schumacher, S. (2001). Research in education. Priscilla McGeehon.

MEB. (2018). Fen bilimleri dersi ögretim programı ilkokul ve ortaokul (3, 4, 5, 6, 7 ve 8. siniflar). MEB.

Miles, M., \& Huberman, M. (1994). Qualitative data analysis (2 ${ }^{\text {nd }}$ ed.). Sage Publications, Inc.

Ocak, İ., \& Hocaoglu, N. (2018a, July 16-20). The development of a scale on coconstructivism in Science courses. Hands-on Science, Advancing Science, Improving Education. Barcelona.

Ocak, İ., \& Hocaoğlu, N. (2018b, October 26-28). Fen bilimleri dersinde birlikte yapılandırmacılık ve bazı değişkenler açısından incelenmesi. Uluslararası Necatibey Ĕ̆itim ve Sosyal Bilimler Araştırmaları Kongresi Unesak, Balıkesir.

Özgür, B. (2008). Perceptions of $4^{\text {th }}$ and $5^{\text {th }}$ grade primary school students and their teachers about constructivist learning environments in science and technology courses [Unpublished doctoral dissertation]. Orta Doğu Teknik Üniversitesi.

Philip, T. M., \& Gupta, A. (2020). Emerging perspectives on the co-construction of power and learning in the learning sciences, mathematics education, and science education. Review of Research in Education, 44, 195-217. 
Pilatou, V., \& Stavridou, H. (2008). A case study on primary school students' ideas evolution about simple circuit and parallel connection. International Journal of Learning, 15(5), 143-149.

Reusser, K. (2001). Co-constructivism in educational theory and practice. In J. D. Wright (Ed.), International Encyclopedia of the Social \& Behavioral Sciences $\left(1^{\text {st }}\right.$ ed.) (pp. 2058-2062). Elsevier.

Reusser, K., \& Pauli, C. (2015). Co-constructivism in educational theory and practice. In J. D. Wright (Ed.), International encyclopedia of the social \& behavioral sciences $\left(2^{\text {nd }}\right.$ ed.) (pp. 913-917). Elsevier.

Schermelleh-Engel, K., Moosbrugger, H., \& Müller, H. (2003). Evaluating the fit of structural equation models: Tests of significance and descriptive goodness-of-fit measures. Methods of Psychological Research, 8(2), 23-74.

Sherif, M. (1936). The psychology of social norms. Harper.

Singh, K. (2007). Quantitative social research methods. SAGE Publications.

Speed, B. (1991). Reality exists O.K.? An argument against constructivism and social constructionism. Family Therapy, 13, 395-409.

Steiger, J. H. (2007). Understanding the limitations of global fit assessment in structural equation modeling, Personality and Individual Differences, 42(5), 893-898.

Tavşancıl, E. (2010). Tutumların ölçülmesi ve SPSS veri analizi (4. bs.). Nobel Yayınlar1.

Taylor, P. C., \& Fraser, B. J. (1991). CLES: An instrument for assessing constructivist learning environments. In Annual meeting of the National Association for Research in Science Teaching, Lake Geneva, WI.

Taylor, P. C., Fraser, B., \& White, L. R. (1994). CLES An instrument for monitoring the development of constructivist learning environments. Paper presented at the Annual Meeting of the American Educational Research Association, New Orleans.

Teddlie, C., \& Tashakkori, A. (2009). Foundations of mixed methods research. SAGE.

Tenenbaum, G., Naidu, S., Jegede, O., \& Austin, J. (2001). Constructivist pedagogy in conventional on-campus and distance learning practice: An exploratory investigation. Learning and Instruction, 11, 87-111.

Thompson, B. (2004). Exploratory and confirmatory factor analysis: Understanding concepts and applications. APA.

Urbina, S. (2004). Essentials of psychological testing. John Wiley \& Sons, Inc.

Valsiner, J. (1996). Co-constructionism and development: a socio-historic tradition. Anuario de Psicologia, 69, 63-82.

Yeşilyurt, E. (2012). Yapılandırmacı öğrenme konusunda öğretmen adaylarının yeterliği ölçeği: Geçerlik ve güvenirlik çalışması. Uluslararası Avrasya Sosyal Bilimler Dergisi, 3(7), 29-45.

Yıldırım, A., \& Şimşek, H. (2013). Sosyal bilimlerde nitel araştırma yöntemleri (9. bs.). Seçkin Yayıncılık.

This is an Open Access article distributed under the terms of the Creative CommonsAttributionNonCommercial-ShareAlike 4.0 International (CC BY-NC-SA 4.0). For further information, you can refer to https://creativecommons.org/licenses/by-nc-sa/4.0/ 